Ssciendo Studia Anglica Posnaniensia 55s2 (2020): 445-464

doi: 10.2478/stap-2020-0022

\title{
TAKING ROOT IN FLOATING CITIES - SPACE, ENVIRONMENT, AND IMMIGRANT IDENTITY IN KERRI SAKAMOTO'S FLOATING CITY
}

\author{
JOANNA ANTONIAK ${ }^{1}$
}

\begin{abstract}
Human identity is shaped not only by culture, but also by nature - the environment in which people grow up and live, the places and spaces they visit, work in, and pass on an everyday basis. This people-place bond is particularly important in case of immigrants who are forced to abandon the places they know for a new - and often hostile - environment. This connection between space, environment, and immigrant identity is explored by Kerri Sakamoto, a Japanese-Canadian writer, in her newest novel, Floating City (2018). Focusing on the family narrative of the Hanesakas - and, in particular, the story of Frankie, the oldest son of the family - Sakamoto tells the story of shaping identity through forming a connection with the environment and architecture. The aim of this article is to discuss the way in which Sakamoto presents the people-place bond and its impact on immigrant identity as represented by the connection of the Japanese-Canadians with four elements: water, air, earth, and fire. Furthermore, the article analyses Sakamoto's version of an alternative history of Toronto and the possible solutions to the current environmental crisis it brings. For this purpose, the author uses a mixture of methodological concepts stemming from postcolonial theory and environmental psychology, such as homing desire, rootlessness, place attachment, non-place, and the people-place bond.
\end{abstract}

Keywords: Kerri Sakamoto; place attachment; immigrant identity; family narrative.

\section{Introduction}

In his article for The Huffington Post, Steven Cohen (2015) notes that in the past decade, environmental awareness, steadily growing for over a century, has increased quite significantly. The consumers, concerned about the impact of human activity on the environment, pressure governments and corporations to become more sustainable:

1 Department of Anglophone Literature, Culture and Comparative Studies, Institute of Literary Studies, Nicolaus Copernicus University in Toruń. antoniakjo@umk.pl 
Over time, humans have cut down or damaged at least three-quarters of the world's forests, and that destruction has accounted for much of the excess carbon that is warming the planet. But now, driven by a growing environmental movement in countries that are home to tropical forests, and by mounting pressure from Western consumers who care about sustainable practices, corporate and government leaders are making a fresh push to slow the cutting - and eventually to halt it. In addition, plans are being made by some of those same leaders to encourage forest regrowth on such a giant scale that it might actually pull a sizable fraction of human-released carbon dioxide out of the air and lock it into long-term storage. (Gillis 2014)

As environmental protection becomes an important political issue, not only in developed economies but also in developing ones, it constitutes a paradigm shift, "a shift in values and in a changed awareness of how the world works", affecting the functioning of both institutions and individuals (Cohen 2015).

In cultural and literary studies, the aforementioned shift takes the form of ecocriticism, "an umbrella term for a range of critical approaches that explore the representation in literature (and other cultural forms) of the relationship between the human and the non-human, largely from the perspective of anxiety around humanity's destructive impact on the biosphere" (Marland 2013: 846). Ecocriticism, in turn, led to the emergence of post-humanism, which questions the central position of humans and the existing Great Chain of Being; instead, post-humanism places emphasis on the relationship between human bodies and the environment in which they function (Marland 2013: 856).

The connection between environment, space, and human bodies is the central theme of Floating City, the latest novel by Kerri Sakamoto, a Toronto-based Japanese-Canadian novelist, published in 2018. The aim of this article is to discuss this connection as represented in the novel, and explore how it influences the process of identity formation among the Japanese-Canadians, as well as to briefly analyse Sakamoto's version of an alternative history of Toronto. For this purpose, the article has been divided into four parts. The first part discusses the process of diasporic identity formation in the context of environment, place-nonplace dichotomy, and modern architecture. The second part presents the historical context of Floating City, while the third part explains how Sakamoto draws the connection between the identity of the Japanese-Canadians and the formative power of place/non-place represented by four elements: fire, water, earth, and air. Finally, the fourth part focuses on alternative history, as presented in the novel.

2. Identity formation in the context of places, non-places, and modern architecture

The mere mention of the term 'place' invokes immediate connotations with spatiality both literally - place as "a particular position, point or area in space; a location" or "a portion of space designated or available for or being used by 
someone" - and metaphorically as "a person's rank or status" (Oxford Online Dictionary 2020). This spatiality is also reflected in the word itself as 'place' derives from Latin platea and Greek platria, both meaning 'a broad way' or 'an open space' (Online Etymology Dictionary 2020). ${ }^{2}$ However, the notion of place easily escapes its simple dictionary definitions. According to Martin Heidegger, place is one of the most primal concepts, as dwelling, understood as a continuity between a person and a place, makes human existence possible (in Koops \& Galič 2017: 24). Building on Heidegger's idea, Tim Cresswell (2015: 46) claims that place is a combination of materiality and meaning, with the former consisting of location and locale, defined as a "material setting for social relations" (Cresswell 2015: 12-13), and the latter being "the subjective and emotional attachment people have to place" or "the sense of place" (Cresswell 2015: 14).

John Agnew (1987: 28) notes that place "combine[s] elements of nature (elemental forces), social relations (class, gender, and so on), and meaning (the mind, ideas, symbols)", therefore expanding the understanding of the term to social and cognitive dimensions. As noted by Nancy Easterlin (2016: 227), modern understanding of the notion of place is "a reflection of [its] actual and natural functionality", due to which place has become an object of interest among scholars representing all branches of social sciences and humanities (Lewicka 2011: 207), a tendency reflected in the number of specialised definitions. For instance, Antonio Cristoforetti, Francesca Gennai, and Giulia Rodeschini define place as a space constantly undergoing dynamic redefinition - space which is always subjected to "re-involvement processes" (Cristoforetti, Gennai \& Rodeschini 2011: 225). Similarly, Lawrence Buell notes that

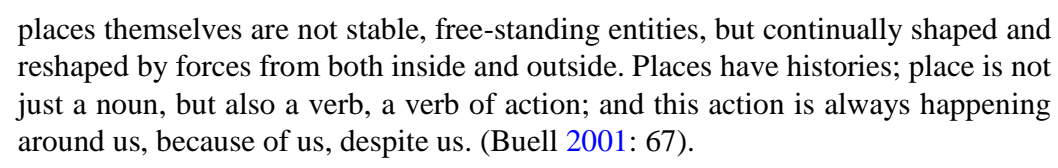
reshaped by forces from both inside and outside. Places have histories; place is not just a noun, but also a verb, a verb of action; and this action is always happening around us, because of us, despite us. (Buell 2001: 67).

Therefore, a place should be seen as a natural space with hidden histories influencing the ways humans interact with their surroundings. In turn, Christopher Schliephake focuses on the connection between place and memory, describing the former as "a spatial container or framework for human action and (...) the stage of historical experience (...) deeply intertwined with both individual as well as collective memory" (Schliephake 2016: 575).

In his book Non-places. Introduction to an anthropology of supermodernity, Marc Augé, a French anthropologist, defines place as "relational, historical, and concerned with identity" (1995: 77). In Augé's definition, place functions as a

2 In fact, the modern English 'place' derives directly from Medieval Latin placea ('place, space') (Online Etymology Dictionary 2020). 
reference point and a source of identification for those who live within its borders or in its vicinity; however, this potential to shape identity stems from emotions and memories ascribed to place in the first place. In contrast, non-place is "a space which cannot be defined as relational, or historical, or concerned with identity" (Augé 1995: 77-78) as it is in case of chain supermarkets, fast food restaurants, airports, and bus and railway stations. According to Augé (1995: 111), the nonplaces are the creations of supermodernity, which favours individualism over social interactions and emotional attachment. Hence, "the space of non-place creates neither singular identity nor relations; only solitude" (Augé 1995: 103).

Augé's understanding of places and non-places aligns with the beliefs of Jan Gehl, who claims that the popularity of modernism in architecture and cityscape development resulted in the creation of city spaces which are unfriendly and depersonalised:

\footnotetext{
dominant planning ideologies - modernism in particular - have specifically put a low priority on public space, pedestrianism and the role of city space as a meeting place for urban dwellers. (...) Architectural trends have gradually shifted focus from the interrelations and common spaces of the city to individual buildings, which in the process have become increasingly more isolated, introverted and dismissive. (Gehl 2010: 3)
}

According to Gehl, the current trends in designing and reshaping city spaces are examples of architecture for the sake of design, rather than for the sake of people. As a result, city dwellers all over the world are exposed to "limited space, obstacles, noise, pollution, risk of accident and generally disgraceful conditions" (Gehl 2010: 3). In turn, those limitations lead to the social and cultural roles of the cityscape being forgotten with "the traditional function of the city space as a meeting place and social forum for the city [being] reduced, threatened or phased out" (Gehl 2010: 3).

Augé's and Gehl's ideas point to the impact that place has on an individual and how individuals bond with the spaces within which they function. This complex phenomenon of people-place bonding is known as place attachment, which can be defined as "a positive affective bond between an individual and a specific place, the main characteristic of which is the tendency of the individual to maintain closeness to such a place" (Hidalgo \& Hernández 2001: 274), "an affective relationship between people and the landscape that goes beyond cognition, preference or judgement" (Riley 1992: 13), "an interplay of affect and emotions, knowledge and beliefs, and behaviours and actions in reference to a place" (Altman \& Low 1992: 5), or "a state of psychological well-being experienced by a person as a result of the mere presence, vicinity, or accessibility of the place" (Korpela 2012: 149). Kalevi Korpela (2012: 149) notes that, apart from individual attachments, there are also collective, shared group and cultural place attachments; 
furthermore, "the object of attachment may not be only the physical environment but also the social relations that a place signifies" (Korpela 2012: 149).

The attachment to place plays a crucial role in the formation of an individual's identity; as noted by Susan Clayton, "a sense of connection to some part of the nonhuman natural environment that affects the way [individuals] perceive and act toward the world; a belief that the environment is important to [individuals] and an important part of who [they] are" (Clayton 2003: 45-46). This identity formation potential found in the environment is attributed to its three characteristics, namely its psychological significance, its importance in fulfilling core self-relevant motives, ${ }^{3}$ and its socio-political significance (Clayton 2012: 168). ${ }^{4}$

The people-place bond is particularly important in the case of members of diasporic communities, who often find themselves displaced and dislocated. ${ }^{5}$ Avtar Brah (1996: 193) notes that feelings of displacement and dislocation are particularly strong among first generation immigrants, as they are forced to assimilate and learn how to function in new economic, political, social, and cultural realties. The impact of those feelings lessens in next generations, whose members see their homeland through the memories of their parents and grandparents. In the context of postcolonial studies and immigrant experience, displacement and dislocation are connected to homing desire, "a process of constructing a place of belonging through collective memory as well as through different practices, such as rituals and traditions" (Brah 1996: 180). Therefore, homing desire is rooted not in the connection with the homeland, but rather with a space which one can call 'a home' - "it is not a desire to return home, but rather a desire for home or a longing to belong" (Brah 1996: 180). ${ }^{6}$

3 Self-relevant motives are understood here as, among others, desires for autonomy and esteem, as well as feelings of efficacy and competence (Clayton 2012: 169).

4 In fact, both "positive and negative perceptions of place are greatly affected by feedback between social relationships, physical location, and self-identity" (Easterlin 2016: 230). Hence, the typologies of place attachment can range from strong love through ambivalence to actual dislike (Easterlin 2016: 230).

5 Although the two terms - displacement and dislocation - are often treated as synonyms, Bill Ashcroft, Gareth Griffiths and Helen Tiffin (2007: 65) note that while displacement refers to the physical act of moving or being forced to move from one place to another and often includes borders, both physical and metaphorical ones, dislocation refers not only to changing places, but also to all the experiences - cultural, psychological, personal, or social-associated or resulting from the act of movement.

6 Brah's concepts of home and homing desire have been challenged in the $21^{\text {st }}$ century by the emergence of digital diasporas which function as "sites of connectivity instead of fixed places of origin and of roots" (Ponzanesi 2020: 988). According to Sandra Ponzanesi (2020: 990), through including emotions, intimacy, and affects characteristic for digital communication, digital diasporas create " "communities of belonging' to reaffirm connections with their homelands, but also (...) establish new relations in the host countries and across other ethnic diasporas" via major social media platforms and specific apps. As a result, they manage to transform the sense of longing into belonging in more than one diaspora space. 
Brah's notion of homing desire is connected to two other concepts related to the people-place bond: rootlessness and place attachment. In the postcolonial and diasporic context, rootlessness can be used to describe the feeling of losing the connection to one's cultural roots, often as a result of the process of displacement. In his article "Homelessness and the meaning of home: Rooflessness or rootlessness?", Peter Somerville compares rootlessness to homelessness, highlighting the fact that "home as roots means one's source of identity and meaningfulness, involving a sense of security which is (...) not the same as emotional security; it is usually called 'ontological security' because it is concerned with one's sense of "being-in-the-world" (Somerville 1992: 533; original emphasis). Hence, it is not surprising that placelessness and rootlessness often result in problems with identity and self-worth:

\begin{abstract}
identity is strongly related to several factors, including the local landscape as a symbolic extension of the self, as well as the sense of 'insideness' in community wherein neighbourhoods and communities become imbued with symbolic meanings. These symbolic meanings, in turn, play a part in an individual's selfdefinition - as, for instance, a friendly, small town inhabitant or, alternatively, a cosmopolitan city-dweller. (Easterlin 2016: 231)
\end{abstract}

The importance of the sense of 'insideness' is also highlighted by Somerville, who claims that the relation between the notion of home and the idea of taking roots implies that the identity of every individual exists within "a structure of social relations which is (...) grounded in a wider web of cultural and linguistic meaning, and it is this wider meaning which familiarises or domesticates the social structure for individual human beings" 'Somerville 1992: 533). This process of domestication is particularly important, as it is only possible to take roots within an ordered social structure.

Christine-Georgiana Voicu (2014: 15) notes that, in case of the members of diaspora communities, place attachment refers to a strong connection with their lost homeland. While seen as the main obstacle in cultural assimilation of immigrants, ${ }^{7}$ place attachment proves to be crucial for their well-being (Scannell \& Gifford 2017: 360). Leila Scannell and Robert Gifford list four features of place attachment which can be observed among immigrants: firstly, there is the need to maintain "physical or symbolic proximity to the important place" through actions such as displaying photographs or returning there every year; secondly, immigrants

7 It needs to be remembered that there is no such thing as 'full cultural assimilation' of first generation immigrants, as they are hardly ever able to completely abandon the culture of their homeland for that of the host country. However, even the descendants of migrants, born in the host country, are often not allowed to fully belong to the host culture, experiencing a sense of non-belonging and displacement similar to that of their parents and grandparents - they are living in the 'in-between' space of non-belonging (McLeod 2000: 214). 
continue to see their homeland as a place "offering a sense of safety and security"; thirdly, the abandoned homeland is perceived as "a safe base for exploration"; and finally, immigrants often react with "grief, alienation, and disorientation" when they are forced to leave their homeland (Scannell \& Gifford 2017: 361-362).

The loss of a well-known and, in some cases, beloved space, combined with the inability to fully connect to the new place and the feeling of being cut off from one's cultural heritage, strongly contribute to immigrant trauma:

\begin{abstract}
[There is] a myriad of complex emotional and physical tasks that must be accomplished by people who leave their homelands. (...) The loss of familiar social networks is especially hard on families and women, who often find themselves isolated, forced to deal on their own with the multiple demands of life in a foreign environment. A downturn in socioeconomic status is the unfortunate norm for most immigrants across the social and educational spectrum (...). Lack of fluency in the host language is frustrating, shameful, and sometimes terrifying for newcomers, for whom a subway ride or a trip to the emergency room with a sick child can turn into a gruelling nightmare. (Perez Foster 2001: 154)
\end{abstract}

Apart from their trauma, the immigrants are also forced to overcome numerous other issues which may additionally contribute to their tumultuous relation with the host country and its environment: redefinition of gender roles which results in the changes in family structure; the requirement to follow mores and values of the host country which are often completely different than those of the homeland; and the quicker and more effective assimilation of younger generations (Perez Foster 2001: 154).

\title{
3. "Bucky" Fuller's Floating City project
}

The protagonist of Kerri Sakamoto's Floating City is Frankie Hanesaka, a Japanese-Canadian living in poverty in a floating house in British Columbia, after his family - consisting of his mother, his stepfather, and four siblings - was cheated out of their land by white Canadians. Just like other Japanese-Canadians, Frankie experiences racial prejudice and discrimination on an everyday basis. Haunted by family secrets and his memories of life in the Tashme Internment Camp, Frankie escapes to Toronto, where he begins his quest to leave his mark on the world. However, Floating City is not only a mere bildungsroman telling the story of a young immigrant chasing his great American Dream and, later, coming to terms with the unforeseen consequences of achieving it, but also the tale of a surprising connection between people and their environment, while giving a brief glimpse into an alternative, more sustainable future. 
Richard Buckminster "Bucky" Fuller, an American architect, inventor, and futurist born in 1895, is a secondary, albeit very important, character is Sakamoto's novel - he is, after all, the force behind Frankie's fascination with architecture and the construction of the eponymous floating cities. Throughout his life, the real-life Bucky focused on developing structures which would be not only easy and cheap to make and move, but also sustainable and available to everyone, regardless of their socioeconomic status. During the post-WWII housing crisis, Fuller proposed numerous solutions to this issue, such as the production of inexpensive, easy-tomove, and environmentally friendly Dymaxion houses, which he designed in the 1920s (Buckminster Fuller Institute 2019).

Another solution for the housing crisis proposed by Fuller, one which is particularly important in the context of the analysed novel, was the creation of Triton City, an organic and self-sufficient floating city located off shore; the floating city would be anchored and connected to the mainland via a number of bridges. Fuller describes the functioning of such a city in Critical Path:

\footnotetext{
[The] shape [of floating cities] and [their] human-life accommodations are not compromised, as must be the shape of the living quarters of ships whose hull shapes are constructed so that they may slip, fishlike, at high speed through the water and high seas with maximum economy. Floating cities are designed with the most buoyantly stable conformation of deep-sea bell-buoys. Their omni-surface-terraced, slop-faced, tetrahedronal structuring is employed to avoid the lethal threat of precipitous falls by humans from vertically sheer high-rising buildings. (Fuller 1981: 332)
}

This idea of the floating cities was partially incorporated by Fuller in his plan for the future development of Toronto, commissioned in 1968 by Toronto City Council (Doolittle 2011).

At the centre of Project Toronto, as Fuller called his development plan, was a great crystal Pyramid, a twenty-stories-high building, housing shops and other commercial spaces; boutiques, restaurants, art galleries, and cafes existing within the Pyramid would be connected via a monorail. At the bottom of the plan, the projects for floating cities were included, connected to the mainland and each other via a series of bridges (Doolittle 2011). Those floating cities, designed by a man far ahead of his times, became one of the central elements in Sakamoto's novel, haunting the fictional Frankie throughout his life.

\section{The Japanese-Canadians and the formative power of four elements}

From the first words of her novel, Sakamoto draws a connection between the Japanese-Canadians and water, the element which encompasses and affects all spheres of their lives. Firstly, water constitutes a route through which the Japanese immigrants arrive in Canada. Furthermore, it is on water where Frankie and his family are forced to take root after being robbed of and chased away from their land: 
They'd had a garden once, not a bit grand. (...) It was on land, of course. A normal house like everyone else's, before they had to leave. (...) Then the men had come. One worked, he said, in the office at the mill; the others were his friends - business friends. They warned Taiji that the City would be coming to chase him off his land because they didn't want Japs cluttering up the waterfront any longer. But this man would do Taiji a good turn and buy the lot from him before he got thrown off for a pittance. He was fair, he said, and generous - too generous, and too soft in the head - placing bills in Taiji's hand: fifty dollars. (Sakamoto 2018: 12-13)

Water also becomes the means of employment for many Japanese and Chinese immigrants, whose first job upon arriving in Canada is that of a log driver, a worker responsible for moving logs from forests to sawmills and pulp mills downstream, using the current of a river. Although this water-bound profession provides the immigrants with an opportunity to gain a foothold in Canada, it also requires great physical strength and agility and, while exciting and exhilarating, can be particularly dangerous or even deadly, highlighting the capricious nature of the element (Sakamoto 2018: 3).

The Japanese and Chinese immigrants perceive water as the source of freedom and equality since "nobody owns the water" (Sakamoto 2018: 44). It is the belief in the equalising power of the element that sparks Frankie's idea to build a floating hotel and a floating garden, catering to the needs of the newly arrived Asian immigrants:

Their venture would produce a hotel two storeys high with a potbelly stove and a wool blanket in each room. Visiting lumbermen needed a place to stay. Newcomers. People who couldn't afford to stay in the Arlington Hotel in town. So what was the problem?

"No land!” said Mr Fung (...) "Cost too much! Pie in sky!"

"Float it!" Frankie blurted. Like his own house. (...) "Who needs land?" He'd learned that when the men had come to board up their house. Instead of letting anyone tear it down, Taiji had set onto the water, anchored it on the inlet. (...)

A floating hotel. Guests could look out their window either to shore-like his mother did from her chair-or to the forest across the inlet.

"They could fish for dinner!" Frankie cast a line across the cramped room and reeled it back in.

Mr Fung squinted his squinty eyes at the boy. "How to build?" (...) That was easy as pie. Build a house, only bigger, with two storeys instead of one. Put it on a raft and anchor it in the harbour.

Mr Konga (...) wanted it as fine as the Arlington Hotel, but at a cheaper cost. With a restaurant and a barbershop. And a beer parlour. People would line up for their ten-cent glass of beer.

And ice cream, thought Frankie. And a garden: a floating garden with flowers bobbing atop the sea. (Sakamoto 2018: 17-18)

Although plagued with problems during its construction - with one of the workers falling from the scaffolding and breaking his neck - the Hotel on the Sea turns 
out to be a great success among the young Japanese and Chinese bachelors. However, everything changes after the attack on Pearl Harbour, and in January 1942 , the hotel burns down, probably as a result of arson. Nonetheless, by this point, the Japanese families are being displaced from the shoreline and the freedom offered to them by water, further into the mainland, plunged straight into the harshness of mountains and mercilessness of the internment camps. For the Japanese-Canadians who have become attached to water, either living on its surface or in its vicinity, such a sudden transition, combined with the increase in racial discrimination, is a particularly brutal one: upon their arrival to the Tashme Internment Camp, they find themselves rootless again.

In the novel, water is also shown as both a transformative force and an immensely powerful and holy source of protection. During their internment in the Tashme Camp, Frankie and his family agree to get baptised; however, their decision is motivated by practical rather than spiritual reasons, as the Hanesakas see their baptism simply as an additional line of defence against tuberculosis (Sakamoto 2018: 54). Water poured on the heads of the Hanesakas transforms them, cleansing them of their Japanese influences and confirming their Canadian identity, within the confines of the space designed and established for the sole purpose of separating the Japanese aliens from the Canadian society. Interestingly enough, water remains at the centre of the whole ritual, as the Hanesakas bow before the bowl filled with water, come into contact with it and, finally, thank God for it. Yet, from that moment, the depiction of water changes - it is no longer a source of freedom, but a destructive force. During Frankie's stay in Toronto, the city is devastated by the tropical hurricane:

\footnotetext{
Below them, hydro poles toppling, bobbing like toothpicks, cars, houses crumpled and carried along, trees blown horizontal. People were clinging to the roofs of cars and houses, or whatever remained of them. It was a tide of things, the built world overtaken. (...) Frankie and Bucky watched the furious undertow claw back chunks of the city. A firetruck overturned helplessly as its siren screeched then was snuffed as the men inside struggled to get out. (Sakamoto 2018: 126)
}

The deluge, described as almost biblical in proportion, is not only a testament to the destructiveness of water, but also a harsh reminder that it "can affect the workings of death" (Chevalier \& Gheerbrant 1994: 1085) as it claims thirty-five lives, washing them away from existence (Sakamoto 2018: 134-135). For those Japanese-Canadians robbed of their homes during the flood, water stops being the element in which they can root themselves.

The second element to which the Japanese-Canadians become attached and which has a great impact on their identity is earth, represented in the novel by the Tashme Internment Camp and its surroundings. Even the name, 'Tashme', is connected directly to earth, or, to be more precise, to what is below it: "the 
government named it Tashme for Taylor, Shirras and Meade, the principals of a mining venture that had failed (...) half a century ago and had left behind a ghost town" (Sakamoto 2018: 50). The presence of the abandoned mines, the prospectors about whom Frankie learns at school, and the oppressive nature of the mountains surrounding the camp, all point to the harshness and demanding and restrictive nature of this element.

Earth - and, by proxy, the Tashme Internment Camp - is also presented as an element connected to death and decomposition. During one of his exploration trips in the area surrounding the camp, Frankie discovers an old, abandoned cemetery; as he reads inscriptions on the long-forgotten gravestones, he starts to perceive the existence of the cemetery as an omen of the gloomy future lying ahead of the Japanese-Canadians - they would die far away from their homes, buried in the unfriendly land and soon forgotten by those who would come after them (Sakamoto 2018: 50-51). Despite its atmosphere, the cemetery becomes an important space for Frankie, his sanctuary. It is where he brings Reiko and where he continues to meet with her in secret to have sex. In fact, it is on the cemetery ground where their first child is conceived; the pregnancy ends in miscarriage, almost as if the cemetery claimed back the life created within its borders.

While Frankie and his two older siblings, Yas and Aki, cannot form a strong connection with Tashme and the surrounding area, constantly drawn to the nearby river, two of the youngest Hanesaka children, Julia and Augusta, take root in the place almost immediately. The young girls use the architectural structures of the ghost town as the foundation for their new Canadian identities - they organise the theatre company, bringing Western culture to the prisoners:

\begin{abstract}
Augusta squeezed [Frankie's] hand and then slipped a piece of paper into it. He glanced into his palm. It was a list: one yard of red satin, two spools of red thread, five pairs of white gloves, one jar of black shoe polish. (...) Then came curtains, chairs, clothing, paint, wood: whatever was on Augusta's list. With inspiration from Shirley Temple and assistance from Julia, Augusta was pioneering the 3-T Club: Tashme Talent Theatre. (Sakamoto 2018: 57-58)
\end{abstract}

The quick and strong attachment to the desolate and dilapidated space exhibited by Frankie's sisters can stem from their higher levels of cultural assimilation, which are reflected not only by their behaviour, but also their very Western names - Julia and Augusta. Hence, it is not surprising that they are the only two members of the Hanesaka family who decide to stay in Tashme after the end of the war.

Another character which takes root in Tashme is Reiko, Frankie's wife. Although initially happy to move in with Frankie into the Cloud Tower, she soon starts to experience vertigo: 
(...) Reiko had begun to feel the oddest sensation of their apartment building leaning to one side, maybe even toppling. Just what was anchoring it below? (...) [Frankie] did notice that his wife quivered with each creak or whistle of wind at the window. That she rarely stood at the window, and she often rapped her broom on the floor and walls at echoing voices and footsteps. (Sakamoto 2018: 180; original emphasis)

Unlike Frankie, Reiko seems to crave the stability and order provided by earth she feels uprooted in Toronto, unable to connect with people who see her only as an alien, "as if she weren't Canadian-born and bred, as if she couldn't understand English just fine, thank you very much" (Sakamoto 2018: 180; original emphasis). She misses the earthiness of Tashme, a feeling of "sameness and order" (Sakamoto 2018: 180) provided by the space with which she is emotionally and spiritually connected, a place where her father's spirit lingers and where she has spent the happiest moments of her life (Sakamoto 2018: 180-181).

The third element - air - becomes associated with life after the camp, although the freedom it provides is different from that provided by water. After the war, Frankie leaves the Tashme Interment Camp and moves to Toronto, leaving his family and Reiko behind, with a promise of sending for them soon. When in Toronto, he starts working for Uri Slonemsky, an architect of Jewish descent, who introduces him to the idea of buildings before people. Uri, hired to design and build the Towers of Finance, does not really feel responsible for the fate of the people displaced during the construction of the high-rises. Uri ignores his wife's pleas to revitalise the area inhabited by the destitute and to place the wellbeing of people before the architecture; instead, he shifts the blame, claiming that "the city, the developers, the banks" are responsible for people's suffering he has just been hired to "design the building [and] to make something beautiful from [the] blight" (Sakamoto 2018: 128). When he finally decides to construct his own complex of high-rises, Frankie takes a page from Uri's book. Upon learning from Uri and Hannah, Uri's wife, that the City is planning to buy land from people living close to the shoreline, Frankie uses their difficult situation the damage done to their property by the tropical hurricane - to buy their land for a pittance (Sakamoto 2018: 136). Later, Frankie sells the land to the City for much more than he paid for it, recreating the way in which his family and many other immigrant families were treated when they were forced out of their houses: being paid for their properties much less than they were worth.

Using the money from the City Hall, Frankie starts building his Tomorrow Living for Today, with the Cloud Tower as the crown jewel of the whole complex:

Frankie envisioned his high-rise apartments here, his Tomorrow Living for Today. First one, then another, then another, all across the waterfront, all with banks of windows to the lake and their backs turned to the city, hoarding their view. Then, 
like a beacon, a tower, his own Tower of Finance. So high, he'd call it Cloud Tower. Bucky would like that. He closed his eyes and envisioned its top lost in the clouds and its base buried in snow, so that it seemed to float in the mid-sky, untethered at each end. (Sakamoto 2018: 145)

Although the construction of the Tomorrow Living for Today complex turns out to be a great success, with all the apartments being sold or rented, it comes at a great personal cost for Frankie. Firstly, his stepfather dies when climbing the stairs leading to the top of the building, his death attributed to bad luck brought by the number four (Sakamoto 2018: 174). Furthermore, living in the Cloud Tower seems to have a negative effect on Yuri, Frankie and Reiko's son: the boy does not grow, does not speak, and his psychological and mental development is stilted and slow (Sakamoto 2018: 164). Finally, the boy disappears during the grand opening of the Cloud Tower, only to be found dead on the river bank a few months later (Sakamoto 2018: 185). The disappearance of Yuri leads to the further disintegration of Frankie's family - his wife leaves him and returns to the former Tashme Internment Camp, while his mother and sisters turn away from him as he remains locked in the ivory tower of his own creation.

However, it is not only Frankie's family that suffers because of the Cloud Tower. His high-rise apartments affect the people who live at their feet, blocking the sun and forcing them to live in cold and darkness:

Voices of children came straggling around the bend. "You are my sunshine!" they
chirped. A ring of mothers clasping the hands of pale toddlers and cane-wielding elderly
was forming around the base of the tower. Aki recognised the families who lived in two
old tenement buildings (...). Cramped cold-water flats that decades ago housed returning
soldiers from the war and their families. The buildings were separated by a dusty, rusting
playground filled with broken see-saws and swings that rattled in the wind. Laundry
hung out, but never seemed to dry because there was no sunlight in the shadow of
Frankie's high-rises (...). Only gloom. (Sakamoto 2018: 191-192)

The Cloud Tower is represented in the novel as a non-place with no identity of its own, a parasitic space which sucks the life out of all the people living within its shadow. ${ }^{8}$

Paradoxically, the parasitic Cloud Tower was built as a result of Frankie's fascination with air and freedom it provides, instilled in him by Bucky. Early in their friendship, Frankie listens to one of Bucky's lectures - "We are not trees rooted to the land. We can conquer the vapour sphere, expanding ever outwards.

8 The construction of the Cloud Tower led to the emergence of what Nixon would refer to as spatial amnesia - the people who live in the area surrounding the building are imaginatively (and, in case of some, physically) removed and remain erased from the collective memory (Nixon 2011: 151). 
To the moon and back!" (Sakamoto 2018: 110) - and cannot forget about the meaning behind his words, the promise of climbing the social ladder. However, it is not until he and Bucky fly through the hurricane on Cloud Nine, Bucky's flying dome, that Frankie starts to think about the construction of his own highrises (Sakamoto 2018: 124-127).

Yet, Frankie's fascination with air and his compulsion to devote his life to this element stem from his personal need to forget about his past. When Bucky mentions the idea of a floating city for the first time, Frankie, although intrigued, does not want to return to his childhood experiences of living on the sea (Sakamoto 2018: 131). As he associates water with his childhood poverty, and earth with discrimination and imprisonment, Frankie makes a conscious decision to cut himself off from them; instead, choosing the element favoured by the representatives of the group he really wants to belong to: the educated and sophisticated white Canadians.

The last element - fire - is presented as a destructive force. In fact, it is mentioned in the novel only once, when the Hotel on the Sea burns down: "On the last night, fire broke out at Hotel on the Sea. Mr. Fung, drowsing at the front desk, was roused when his wall of coins, down to a few paltry piles, grew hot under his fingertips; he escaped easily. The balconies collapsed after the remaining bachelors dove off to save themselves" (Sakamoto 2018: 46). Although the origin of the fire remains unknown, it is suggested that it was set to the structure deliberately, an example of growing resentment towards the Japanese-Canadians. Therefore, fire is not only destructive, but can be also used as a tool to punish the immigrants for the actions of their countrymen, to clean the land of those who are deemed undesirable. This destructive and cleansing nature of fire and its use as a tool of punishment is highlighted when Frankie and his family learn about the bombing of Hiroshima and Nagasaki; although, the word 'fire' is never used by the characters, they are aware that both cities and their inhabitants were burnt out of existence.

\section{Floating City as a cautionary tale}

Although Floating City, in a classically Sakamotian manner, is a tale of family relations and immigrant identity, the reality presented in it can be described as slightly alternative; in fact, at the beginning of the novel Sakamoto states that

[t]he timeline of Floating City coincides loosely with real historical events, including the internment of Japanese Canadians in World War II and various incidents and landmarks in the developments of post-war Toronto. It is not intended to follow the precise history of what was, but rather to imagine a story that might have been. (Sakamoto 2018: vii) 
It is within this 'story that might have been' that Sakamoto discusses the connection between people, architecture, and environment, embodied by Torosa, a floating city that Frankie and Bucky construct off the shore of Toronto. The rather primitive prototype of Torosa is the floating hotel and garden envisioned by Frankie during his childhood in Port Alberni; however, both the Hotel at the Sea and Torosa are based on the same belief, namely freedom resulting from the unrestrained movement of water: "three-quarters of our planet Earth is covered with water which may float organic cities. Floating cities pay no rent to landlords" (Sakamoto 2018: 22).

Torosa, conceived and created by Bucky and Frankie, is not merely a meeting place, but also a green and self-sustainable, friendly and organic space created with people in mind, allowing them to live in harmony with each another and nature?:

\footnotetext{
The Floating City was neither ship nor edifice but hive for living, anchored at its shore with schools, supermarkets, light industry; with adjacent flower and vegetable gardens. It could even begin to generate the energy necessary to sustain itself with a floating wind turbine farther out on the lake - the first of its kind. The gateway to Torosa would be a university built by Uri: a glass pyramid echoing the water and sky, and the triangular building blocks of Bucky's Floating City; it would be a Temple of Learning. (Sakamoto 2018: 228)
}

Through the construction of the floating city, Bucky and Frankie hope that they will be able to forge a community based on equality and tolerance and eradicate such social issues like homelessness and unemployment (Sakamoto 2018: 228). Apart from being a meeting place for people, Torosa is also a space where the elements of air, water, and earth mix and work together to create a friendly environment. However, the mixing of the elements is not accidental, but engineered - drawing from his experiences, Frankie chooses positive aspects of the three elements: the nurture and freedom of water, stability and fertility of earth, and independence and power of air. Furthermore, while Sakamoto incorporates the glass pyramid from Fuller's Project Toronto (albeit changing its function from commercial to educational), she also shows the shift in Frankie's perception of architecture from buildings before people to people before buildings - he finally decides to demolish Cloud Tower to not only create more space and light for people to live in, but also to free himself from the burden which "clouded his head and weighted his heart" (Sakamoto 2018: 232).

9 The idea of living in harmony with nature presented in Sakamoto's novel seems to reference the modern georgic - love of the environment based on daily working knowledge and taking the responsibility for the natural world (Garrard 2004: 113-114). 
The construction of Torosa coincides with changes in Frankie's personal life. His second son, Arnon, is born after a complicated pregnancy. However, unlike Yuri, raised in the coldness of the Cloud Tower, Arnon, nourished by water, develops normally, growing stronger with every passing day. The creation of Torosa marks not only a new start for Frankie, but also the return to his roots. However, he is no longer the same young man hopelessly trying to find his place in the world: as Frankie's life and career come full circle - from water, through earth to air, and then back to water - he embraces all parts of his identity (watery childhood, earthly youth, and airy adulthood), finally acknowledging that he is rooted not in one, but in three elements. At peace with himself and ready to face his mistakes, he ensures that families - often the immigrant ones - he uprooted all those years ago are housed on Torosa; he also invites to Torosa the JapaneseCanadians still living in the former Tashme Internment Camp, the homeless, and those whom he robbed of sunlight:

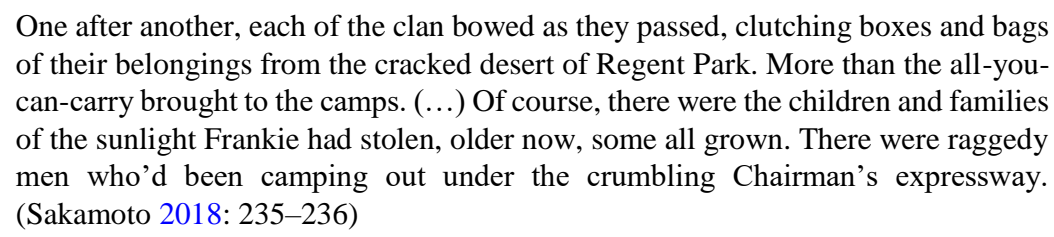

Through embracing his heritage, Frankie can also finally reconcile with his mother and his sisters. Torosa is, therefore, a friendly space open to everyone and a meeting place for the marginalised - the immigrant, the poor, the homeless, the forgotten. This egalitarian quality of Torosa is rooted - or rather anchored - in freedom provided by water, and in the belief in architecture created for people and supporting nature.

At the same time, as a recreation of Frankie's first floating garden built in Port Alberni, Torosa becomes the embodiment of an English pastoral, which Rob Nixon defines as a "garden idyll, where neither labour nor violence intrudes" (Nixon 2011: 245). Yet, the pastoral character of the eponymous floating city seems to be too ideal - while it constitutes hortus conclusus (Nixon 2011: 245), it was misery and suffering of the marginalised people invited to inhabit it that made the construction of the idyllic Torosa possible. As a result, it is impossible to look and live at Torosa without acknowledging prejudice and discrimination, whether racial or socioeconomic, which lay at its foundation.

\section{Conclusions}

In Floating City Sakamoto draws a connection between space, environment, and immigrant identity, and shows how different ways of developing the cityscape contribute to changes in the relations within immigrant families and influence the 
people-place bond. The Cloud Tower, the embodiment of a non-place characterised by the coldness and harshness of air, leads to the disintegration of interpersonal relations. In fact, it goes even further, affecting the physical and psychological dimensions as well - stunning the development of children, weakening the elders, and stirring anxiety and a sense of dread in those who are forced to live in its shadow. The glass tower becomes the ivory one, isolating Frankie from those who care about him. In contrast, within the friendly space of Torosa, the people and relationships they form seem to, at least initially, flourish like flowers and vegetables in the rooftop gardens of the floating city.

The impact of the Cloud Tower and Torosa become embodied in the characters of Yuri and Arnon, Frankie's sons, whose life forces seem to be connected with their father's architectural creations. Sakamoto also highlights that the connection with the natural environment should be seen as more important than the connection with a man-made one, giving primacy to peopleand eco-friendly architecture. Interestingly enough, it is water - not air - that becomes the source of freedom for the characters. Although it functions as a place of exile for Frankie and his family, and despite its capricious and cruel nature water gives life, but can also take it away - it is the equalising character of water that makes it a safe space for those marginalised. However, water and air are not the only elements which seem to have an impact on the identity and familial relations of the Japanese-Canadians. Earth, embodied by the Tashme Internment Camp, is presented in the novel as an oppressive element, robbing the JapaneseCanadians of their freedom and instilling in them the belief that they are less human than the white Canadians. At the same time, though, for the Westernised and culturally assimilated Julia and Augusta, it becomes a natural habitat and a confirmation of their new Canadian identity; meanwhile, for Reiko, the earthliness of Tashme is a source of stability and order she cannot find in the airiness of Toronto. Finally, fire in Floating City is depicted as destructive, a force which can be used to punish and abuse those who are deemed as the Others, the undesirables, and a threat to Canadian society.

Sakamoto's alternative history of Toronto cityscape development can be seen as a plan for the future, a possible solution for the environmental catastrophe of the $21^{\text {st }}$ century. Humans, as a species, should focus on creating and developing spaces which not only encourage establishing and sustaining close relations between people, but are also sustainable and eco-friendly. ${ }^{10}$ It is time to

10 Interestingly enough, Bucky's (pipe)dreams of floating cities may soon come true. In 2019, UN teamed up with Oceanix, the Massachusetts Institute of Technology, and the Explores Club to start working on designing Oceanix City, a floating city created out of hexagonal platforms anchored to the seabed (Wright 2019). Another floating city, named the Floating Island, designed by Seasteading Institute from San Francisco, is expected to open by 2022 (Arch20 2019). 
acknowledge that land is not only non-reusable, but also unavailable to everyone equally - as highlighted by Bucky, "in the future, almost everyone would have to live on water as land became used up" (Sakamoto 2018: 223). Through creating a slightly alternative timeline in her novel, Sakamoto shows her readers that floating cities, a utopian and futuristic idea, may soon become not only a reality, but also a necessity - a gloomy testament to humans' inability to see the connection between themselves, the spaces they create and the environment.

At the same time, Sakamoto's utopian vision seems slightly naïve, as it does not take into consideration numerous practical aspects of living offshore, such as the availability of drinking water or the problem of waste and sewage disposal, and assumes the peaceful and harmonious coexistence of people of different cultural and socioeconomic backgrounds. However, the most troubling feature of Torosa is that it is ultimately inhabited by those deemed undesirable: the poor, the immigrants, the elderly, the homeless. As a result, the floating city is in danger of becoming the dumping ground for those scarified for the sake of progress: the masses of developmental refugees and uninhabitants, ${ }^{11}$ disappearing from both sight and mind of the nation fixated on sustainable development.

\section{REFERENCES}

Agnew, John A. 1987. Place and politics: The geographical meditation of state and society. Allen \& Unwin.

Altman, Irwin \& Setha M. Low. 1992. Place attachment. Springer.

Arch20. 2019. This is the world's first floating city and you can visit it in 2022. https://www.arch2o.com/first-floating-city-2020/ (Accessed 26/02/2020.)

Ashcroft, Bill, Gareth Griffiths \& Helen Tiffin. 2007. Post-colonial studies: The key concepts. (2nd edn.) Routledge.

Augé, Marc. 1995. Non-places. Introduction to an anthropology of supermodernity. Verso.

Brah, Avtar. 1996. Cartographies of diaspora: Contesting identities. Routledge.

Buckminster Fuller Institute. 2019. Dymaxion house. https://www.bfi.org/about-fuller/bigideas/dymaxion-world/dymaxion-house (Accessed 22/02/2020.)

Buell, Lawrence. 2001. Writing for an endangered world: Literature, culture, and environment in the U.S. and beyond. The Belknap Press.

Chevalier, Jean \& Alain Gheerbrant. 1994. A dictionary of symbols. Penguin.

Clayton, Susan D. 2003. Environmental identity: A conceptual and an operational definition. In Susan D. Clayton \& Susan Opotow (eds), Identity and the natural environment: The psychological significance of nature. MIT Press. 45-65.

11 The term 'developmental refugees' was coined by Thayer Scudder to describe the plight of the people displaced during the construction of megadams (Nixon 2011: 152). The idea of a developmental refugee overlaps with that of the uninhabitant, a person who is removed from public awareness, "existing in a kind of vaporized dwelling" (Nixon 2011: 153). 
Clayton, Susan D. 2012. Environment and identity. In Susan D. Clayton (ed.), The Oxford handbook of environmental and conversation psychology. Oxford University Press. 164-180. DOI: 10.1093/oxfordhb/9780199733026.013.0010

Cohen, Steven. 2015. The growing level of environmental awareness. Huffington Post, https://www.huffpost.com/entry/the-growing-level-of-envi_b_6390054 (Accessed 19/02/2020.)

Cresswell, Tim. 2015. Place: An introduction. (2nd edn.) Wiley Blackwell.

Cristoforetti, Antonio, Francesca Gennai \& Giulia Rodeschini. 2011. Home sweet home: The emotional construction of places. Journal of Aging Studies 25(3). 225-232. DOI: 10.1016/j.jaging.2011.03.006

Doolittle, Robyn. 2011. From great glass pyramids to gigantic Ferris Wheels; a history of Toronto waterfront development. https://www.thestar.com/news/gta/2011/08/31/from_great_glass_pyramids_to_gigant ic_ferris_wheels_a_history_of_toronto_waterfront_development.html (Accessed 22/02/2020.)

Easterlin, Nancy. 2016. Ecocriticism, place studies, and Colm Tóibín's “A Long Winter”: A biocultural perspective. In Hubert Zapf (ed.), Handbook of ecocriticism and cultural ecology. De Gruyter. 226-248. DOI: 10.1515/9783110314595-014

Fuller, Buckminster. 1981. Critical path. St. Martin's Press.

Gehl, Jan. 2010. Cities for people. Island Press.

Garrard, Greg. 2004. Ecocriticism. Routledge.

Gillis, Justin. 2014. Restored forests breathe life into efforts against climate change. The New York Times 24 December. https://www.nytimes.com/2014/12/24/science/earth/restoredforests-are-making-inroads-against-climate-change-.html (Accessed 19/02/2020.)

Hidalgo, M. Carmen \& Bernardo Hernández. 2001. Place attachment: Conceptual and empirical questions. Journal of Environmental Psychology 21(3). 273-281. DOI: 10.1006/jevp.2001.0221

Koops, Bert-Jaap \& Maša Galič. 2017. Conceptualizing space and place: Lessons from geography for the debate on privacy in public. In Tjerk Timan, Bryce C. Newell \& Bert-Japp Koops (eds.), Privacy in public space. Conceptual and regulatory challenges. Edward Elgar Publishing. 19-46.

Korpela, Kalevi M. 2012. Place attachment. In Susan D. Clayton (ed.), The Oxford handbook of environmental and conversation psychology. Oxford University Press. 148-163. DOI: 10.1093/oxfordhb/9780199733026.013.0009

Lewicka, Maria. 2011. Place attachment: How far have we come in the last 40 years? Journal of Environmental Psychology 31(3). 207-230. DOI: 10.1016/j.jenvp.2010.10.001

Marland, Pippa. 2013. Ecocriticism. Literature Compass 10(11). 846-868. DOI: 10.1111/lic3.12105

McLeod, John. 2000. Beginning postcolonialism. Manchester University Press.

Nixon, Rob. 2011. Slow violence and the environmentalism of the poor. Harvard University Press.

Online Etymology Dictionary. 2020. Place. https://www.etymonline.com/word/place (Accessed 20/02/2020.)

Oxford Online Dictionary. 2020. Place. https://www.lexico.com/definition/place (Accessed 20/02/2020.)

Perez Foster, RoseMarie. 2001. When immigration is trauma: Guidelines for the individual and family clinician. American Journal of Orthopsychiatry 71(2). 153-170. DOI: 10.1037/0002-9432.71.2.153 
Ponzanesi, Sandra. 2020. Digital diasporas: Postcoloniality, media and affect. Interventions: International Journal of Postcolonial Studies 2(8). 977-993. DOI: 10.1080/1369801X.2020.1718537

Riley, Robert B. 1992. Attachment to the ordinary landscape. In Irwin Altman \& Setha M. Low (eds), Place attachment. Springer. 13-35. DOI: 10.1007/978-1-4684-8753-4_2

Sakamoto, Kerri. 2018. Floating city. Alfred K. Knopf Canada.

Scannell, Leila \& Robert Gifford. 2017. Place attachment enhances psychological need satisfaction. Environment and Behaviour 49(4). 359-389. DOI: 10.1177/0013916516637648

Schliephake, Christopher. 2016. Literary place and cultural memory. In Hubert Zapf (ed.), Handbook of ecocriticism and cultural ecology. De Gruyter. 569-589. DOI: 10.1515/9783110314595-031

Somerville, Peter. 1992. Homelessness and the meaning of home: Rooflessness or rootlessness? International Journal of Urban and Regional Research 16(4). 529-539.

DOI: 10.1111/j.1468-2427.1992.tb00194.x

Voicu, Christine-Georgiana. 2014. Exploring cultural identities in Jean Rhys' fiction. De Gruyter Open. DOI: 10.2478/9788376560687

Wright, George. 2019. Floating cities - fantasy or the future? BBC News. https://www.bbc.com/news/world-47827136 (Accessed 26/02/2020.) 